YEARBOOK

of ANTITRUST

and REGULATORY

STUDIES

www.yars.wz.uw.edu.pl
Peer-reviewed scientific periodical, focusing on legal and economic issues of antitrust and regulation. Creative Commons Attribution-No Derivative Works 3.0 Poland License.

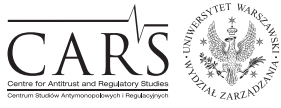

Centre for Antitrust and Regulatory Studies, University of Warsaw, Faculty of Management www.cars.wZ.uw.edu.pl

\title{
Energy Security of West Africa: the Case of Natural Gas
}

\author{
by
}

Elias Zigah*

\section{CONTENTS}

I. Introduction

1. Background

2. Importance of natural gas

II. Literature review

III. Methodology

1. Introduction

2. Gas Supply Security Index (GSSI)

2.1. Gas Intensity $\left(\mathrm{G}_{1}\right)$

2.2. Net Gas Import Dependency $\left(\mathrm{G}_{2}\right)$

2.3. The Ratio of Domestic Gas Production $\left(\mathrm{G}_{3}\right)$

2.4. Geopolitical Risk $\left(\mathrm{G}_{4}\right)$

2.5. Gross Inland Consumption $\left(\mathrm{G}_{5}\right)$

IV. Empirical results and discussion

1. Empirical results

2. Discussion

2.1. Cameroon

2.2. Cote d'Ivoire

2.3. Nigeria

2.4. Ghana

3. Recommendation

V. Conclusion and recommendation

* Elias Zigah - a graduate of University of Dundee (MSc in International Energy Studies with Specialization in Oil and Gas Economics from the Center for Energy, Petroleum and Mineral Law and Policy (CEPMLP); research assistant for the UN - CEPMLP Energy Law and Policy Project and a trainee researcher at the Climate Economics Chair in Paris. Article received: 12 September 2019, accepted: 30 September 2019. 


\section{Abstract}

The Gas Supply Security Index (GSSI) is used to assess the security of natural gas supply of four gas producing countries in West Africa using five indicators: Gas Intensity, Net Gas Import Dependency, Ratio of Domestic Gas Production to Imports, Gross Inland Consumption and Geopolitical Risk. This study identified that security of natural gas supply in West Africa is a major challenge as some of the major natural gas producers within the region are highly vulnerable to supply disruptions. Most of the countries studied rely solely on domestic production for supply security. Lack of diversification of supply source and the absence of natural gas storage facilities to safeguard the security of supply were identified as the major factors accounting for the high vulnerability among the natural gas producers within the region.

\section{Resumé}

L'Indice de sécurité d'approvisionnement en gaz sert à évaluer la sécurité d'approvisionnement en gaz naturel de quatre pays producteurs de gaz en Afrique de l'Ouest à l'aide de cinq indicateurs: Intensité gazière, dépendance à l'égard des importations nettes de gaz, ratio de la production gazière nationale aux importations, consommation intérieure brute et risque géopolitique. Cette étude a montré que la sécurité de l'approvisionnement en gaz naturel en Afrique de l'Ouest constitue un enjeu essentiel car certains des principaux producteurs de gaz naturel de la région sont des plus exposés aux perturbations de l'approvisionnement. La plupart des pays étudiés comptent uniquement sur la production nationale pour garantir leur sécurité d'approvisionnement. Le manque de diversification des sources d'approvisionnement et l'absence de stockages de gaz naturel pour garantir la sécurité de l'approvisionnement sont les principaux déterminants de la forte vulnérabilité des producteurs de gaz naturel dans la région.

Key words: energy security; natural gas; Gas Supply Security Index; West Africa.

JEL: Q3, L71

\section{Introduction}

\section{Background}

Africa remains vulnerable to energy security despite efforts from many African governments to tackle key political, economic and regulatory barriers to improving the security of energy supply within the region (IEA, 2011). The International Energy Agency (hereinafter: IEA) in its recent publication 
estimated the energy demand in Africa to grow at a compounded annual growth rate of $2 \%$ between 2016 and 2040 (Fulwood and Bros, 2018). However, the security of the energy supply, along with the reliability and affordability of energy, in Africa to meet its growing demand is still a major challenge even though the continent is rich in energy resources (IEA, 2014).

This paper aims to identify the factors that influence the natural gas supply security of a nation and use them to measure the gas supply security of Ghana, Nigeria, Cote d'Ivoire and Cameroon and rank them according to their supply vulnerabilities. The paper seeks to answer the question:

How vulnerable is Ghana, Nigeria, Cote d'Ivoire and Cameroon to disruptions in natural gas supply security?

\section{Importance of natural gas}

Natural gas has been trending globally, and it is becoming increasingly popular in developing countries as the world's quest for cleaner and cheaper energy increases. As the world transitions towards less carbon-intensive sources of electricity, the demand for natural gas as a fuel of choice is gaining high momentum in the global energy mix (Capece, 2014). 'Natural gas is the second largest energy source in power generation, representing $22 \%$ of generated power globally and the only fossil fuel whose share of primary energy consumption is projected to grow' (World Energy Council, 2016).

Natural gas consumption level has increased from 2181.7 Mtoe in 2000 to 3204.1 Mtoe by the end of 2016 (BP, 2017), making natural gas the third most consumed fuel, accounting for $24 \%$ of global energy consumption. This is exhibited in Figure 1 below. Figure 2 and 3 present the main contributors to the increase in global natural gas production and consumption, respectively.

Figure 1. 2016 Primary Energy Consumption in Mtoe
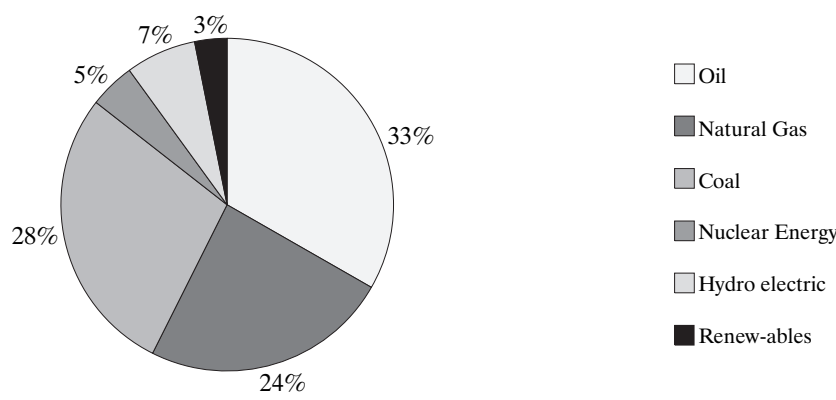

Source: (BP, 2017). 
Figure 2. Global Natural Gas Production in Mtoe

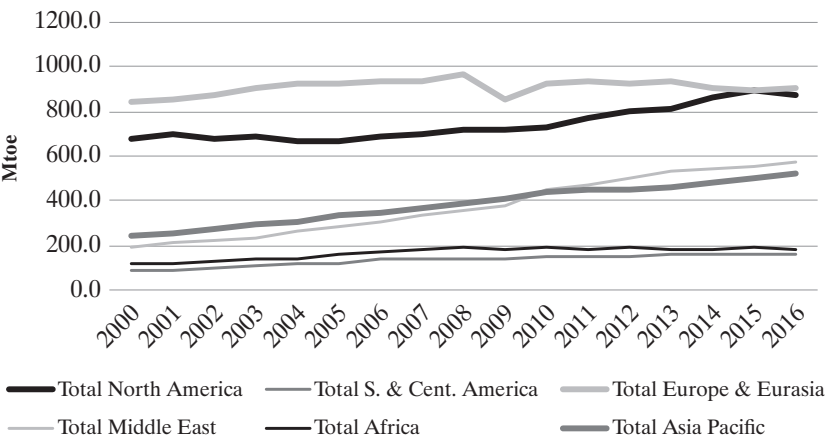

Source: BP, 2017.

Figure 3. Global Natural Gas Consumption in Mtoe

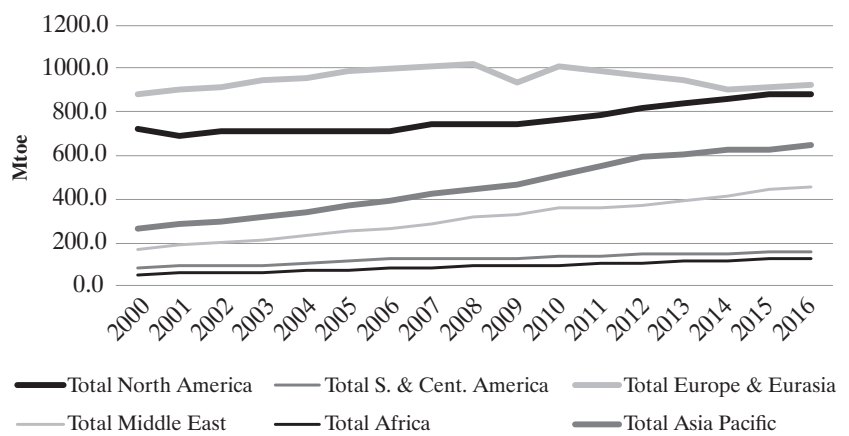

Source: (BP, 2017).

Uninterrupted power supply in West Africa, especially in Ghana and Nigeria, has been undermined by limited access to reliable and economical fuel sources for the past few decades.

According to a study conducted by the Center for Global Development, the power crisis in Ghana during the past decades cost the nation on average of US \$2.1 million in loss of production daily (Kumi, 2017). Similarly, the lack of access to reliable grid electricity in Nigeria forced some companies to spend about $50 \%$ of their income on fueling generators (Somorin and Kolios, 2017). Therefore, securing natural gas as a reliable replacement fuel for expensive oil-based fuels for power generation in West Africa is crucial.

The rest of this paper is organized as follows: Chapter two presents a review of related literature on energy security, particularly focusing on the methodological framework and indicators for measuring energy security. Chapter three discusses the composite gas supply security index methodology 
adopted by this paper to measure the natural gas security of West Africa, while chapter four derives and discusses the composite gas supply security index of the selected countries. Conclusions and recommendations are presented in chapter five.

\section{Literature review}

Estimating the degree of energy security, using various indicators to develop quantitative models, has been widely explored in the literature. However, Cherp and Jewell argued that there is no one fit for all method for measuring energy security, rather, energy security should be measured through the application of an assessment framework sufficiently systematic to ensure scientific rigor and sufficiently flexible to account for specific circumstances and perspectives (Cherp and Jewell, 2010). Also, Ang et al. (2014) claimed that measuring energy security using a simple indicator can be very challenging.

Instead, it is more suitable to evaluate energy security using a basket of indicators (or metrics) that represent the various dimensions it encompasses based on a specific framework. According to them, each of the indicators is given a certain weight according to its perceived importance, and an appropriate aggregation technique is used to combine them to give an index. The energy security indexes derived in this way are termed as composite indexes (Ang et al., 2014). However, Mohsin et al. argued that obtaining an expert opinion in estimating the weights of these indicators is a critical issue, which could pose a difficulty in the aggregation of the Composite index (Mohsin et al., 2018).

Cabalu 2010 and Reymond 2012 used the four GSSI indicators: Gas intensity, Net gas import dependency, Ratio of domestic gas production to total domestic gas consumption and Geopolitical risk, to model a composite index - gas supply security index (GSSI) to compute the gas supply security in Asia and South America respectively (Cabalu, 2010), (Reymond, 2012). Also, D. Pavlović et al. employed the GSSI model to measure the energy security of the Croatian gas market using the following indicators: Energy Import Dependency Index, Energy Intensity, Gross Inland Consumption, Index of National Economy Dependence on Natural Gas, Herfindahl-Hirschman Index, and Shannon-Wiener Index (Pavlović et al., 2017).

Other researchers, such as Mohsin et al. (2018) and Geng and Ji (2013) have also used the composite index model to assess the oil supply security of South Asia and China respectively. The following indicators were used to measure the supply security: Supply risk, which comprises liquidity, 
and geopolitical indicators which were used to assess the risk of physical disruptions to availability and accessibility of oil supply. The infrastructure risk indicator takes into account refinery capacity, while market risk indicators account for oil price volatility, cost, GDP per Capita, US dollar index volatility. The transportation risk indicator looks at the risk of oil transportation and dependency risk indicators measure the ratio of net import over net consumption, diversification of supply and alternative energy uses. Also included among the indicators are energy technologies and efficiency and energy resource reserves indexes.

Chung et al. have developed a similar conceptual framework for evaluating the energy security of South Korea by using four energy security indicators: supply reliability, economy, environment and technology dimensions (Chung et al., 2017). Other comprehensive evaluation indicator systems have also been established by Gupta, 2008; Sovacool and Mukherjee, 2011; MOSES by IEA, 2011; Cherp et al., 2012; Kanchana and Unesaki, 2015; Biresselioglu et al., 2014; Li et al., 2016; Zhang et al., 2015; Franki and Alfredo, 2015; Kisel et al., 2016; Global Energy Institute, 2017.

According to Franki and Alfredo, in general, the appropriate means to measure the degree of energy security is the use of a security indicator (index). However, despite the popularity of composite index models in research literature, some aggregated indicators published in the past years do not record performance during time bands and are, therefore, unable to show trends in energy security performance (Franki and Višković, 2015).

\section{Methodology}

\section{Introduction}

This paper uses the composite Gas Supply Security Index (GSSI) to measure the Gas security of five West African Countries: Nigeria, Ghana, Cote d'Ivoire and Cameroon. Five supply security indicators are selected and used to evaluate the gas security based on previous studies (Cabalu, 2010; Reymond, 2012; Pavlović et al., 2017). The study adopts the composite index GSSI because it is easier to interpret than trying to find a trend in many separate indicators. It also facilitates the task of ranking countries on complex issues in a benchmarking exercise and summarizes complex or multi-dimensional issues, supporting decision-makers. However, if the GSSI is poorly constructed or misinterpreted (if the various stages, for example selection of indicators, choice of model, weights are not transparent and based on sound statistical or 
conceptual principles.), they may send misleading policy messages (Centoni, 2016; Mohsin et al., 2018).

\section{Gas Supply Security Index (GSSI)}

Cabalu (2010) states 'it is preferable to express indicators in the same unit to simplify their aggregation'. Based on a previous study (Reymond, 2012), a value between 0 and 1 is assigned to each of the energy indicators derived below. The gas supply security index (GSSI) is estimated from the quadratic average of the five indicators in each country: Gas Intensity $\left(\mathrm{G}_{1}\right)$, Net Gas Import Dependency $\left(\mathrm{G}_{2}\right)$, Ratio of Domestic Gas Production $\left(\mathrm{G}_{3}\right)$, Gross Inland Consumption $\left(\mathrm{G}_{4}\right)$, and the Geopolitical Risk $\left(\mathrm{G}_{5}\right)$.

The Gas Supply Security Index (GSSI) is expressed as:

Equation 1: Gas Supply Security Index (GSSI)

$$
\operatorname{GSSI}_{j}=\sqrt{\frac{\sum_{i}^{5} 1 \varphi_{i j}^{2}}{5}}
$$

Where $\varphi_{i j}^{2}$ corresponds to indicator $i$ of country $j$. Here the GSSI considers the interactions between the different indicators and highlights countries' sensitivity to the developments in the international gas market. Building on (Cabalu, 2010; Reymond, 2012), this study constructs the GSSI model by adopting a fifth indicator - Gross Inland Consumption $\left(\mathrm{G}_{5}\right)$ from (Pavlović et al., 2017) composite index indicators.

\subsection{Gas Intensity $\left(G_{1}\right)$}

$G_{1}$ measures gas consumption in the economy to the gross domestic product (GDP). It is a ratio of the amount of natural gas required to produce a dollar's worth of goods and services expressed in cubic meter per GDP $\left(\mathrm{m}^{3} / \mathrm{GDP}\right)$. It also demonstrates how efficient the economy is in the use of gas to produce goods and services. Inflation-adjusted GDP is used as the measure of the product of goods and services in the various economies.

Equation 2: Gas Intensity $\left(G_{1}\right)$

$$
G_{1}=\frac{G C_{j}}{G D P_{j}}
$$


Where GC is the total gas consumption the relative indicator $\varphi_{1}$ associated with $G_{1}$ is estimated as:

Equation 3: Relative indicator $\varphi_{1}$

$$
\varphi_{1}=\frac{G_{1}-\min \left(G_{1}\right)}{\max G_{1}-\min \left(G_{1}\right)}
$$

\subsection{Net Gas Import Dependency $\left(G_{2}\right)$}

This is a measure of the total natural import (GM) into country $j$ compared to the total primary energy consumption (TPEC) of country $j$ expressed in a percentage.

Equation 4: Net Gas Import Dependency $G_{2}$

$$
G_{2 j}=\frac{G M_{j}}{T P E C_{j}}
$$

Also, the relative indicator $\varphi_{2 j}$ associated with $G_{2}$ is estimated as:

Equation 5: Relative indicator $\varphi_{2 j}$

$$
\varphi_{2 j}=\frac{G_{2}-\min \left(G_{2}\right)}{\max G_{2}-\min \left(G_{2}\right)}
$$

\subsection{The Ratio of Domestic Gas Production $\left(G_{3 j}\right)$}

This is measured as the ratio of domestic gas production to the total domestic gas consumption. Domestic production is a better indicator of the country's capacity to cope with short-term supply disruptions than domestic reserves, as production excludes gas from stranded reserves which cannot be tapped immediately.

Equation 6: Ratio of Domestic Gas Production $\left(G_{3 j}\right)$

$$
G_{3 j}=\frac{G P_{j}}{G C_{j}}
$$


Where $G P_{j}$ is the total domestic production in country $\mathrm{j}$ and $G C_{j}$ is the total consumption in country $j$. This indicator has a negative correlation with gas supply vulnerability. A high $G_{3 j}$ means country $j$ is highly exposed to the risk of supply disruptions compared with other countries in the study.

The relative indicator $\varphi_{3 j}$ associated with $G_{3 j}$ is expressed as:

Equation 7: Relative indicator $\varphi_{3 j}$

$$
\varphi_{3 j}=\frac{G_{3}-\min \left(G_{3}\right)}{\max G_{3}-\min \left(G_{3}\right)}
$$

\subsection{Geopolitical Risk $\left(G_{4}\right)$}

This supply security indicator is determined by the degree of diversification of gas imports and the associated political stability of these sources. Adjusted Shannon diversity index methodology is used for quantifying such risks by reducing the index from unstable countries.

Equation 8: Geopolitical Risk (G4)

$$
G_{4}=S_{j}=\sum\left(h_{i} m_{i} \operatorname{lnm}_{i}\right)
$$

The limitation of this index is that it does not take account of natural gas production within the country; therefore, for this study, the Shannon-WienerNeumann index has been adjusted to cater for indigenous production.

Equation 9: Adj. Shannon-Wiener-Neumann index

$$
A D j G_{4}=A D j S_{j}=-g c l n c-\sum\left(h_{i} m_{i} \operatorname{lnm}_{i}\right)
$$

Where:

$S_{i j}=$ Shannon diversity index of import flow of gas adjusted for political stability in both the exporting and indigenous country.

$h_{i} \quad$ is the degree of political stability in exporting country $i$.

$g \quad$ is the degree of political stability of the indigenous country. (Both $h_{i}$ and $g_{i}$ are expressed in the interval of $(0,1)$ where 0 denotes extremely unstable and 1 denoting extremely stable.

$m_{1}$ is the share of gas imports from country $i$ in total gas import.

$C$ is the share of consumption from domestic sources. 
The relative indicator $\varphi_{4 j}$ for country $j$ associated with $G_{4}$ is expressed as:

Equation 10: Relative indicator $\varphi_{4 j}$

$$
\varphi_{4 j}=\frac{G_{4}-\min \left(G_{4}\right)}{\max G_{4}-\min \left(G_{4}\right)}
$$

Similarly, this indicator also has an inverse relationship with gas supply vulnerability. This means that a low political stability rating $\left(G_{4}\right)$ suggests high vulnerability to supply disruptions.

\subsection{Gross Inland Consumption $\left(G_{5}\right)$}

The Gross Inland Consumption is the ratio of total gas consumption in country $j\left(T G C_{j}\right)$ and the total population of country $j\left(P_{j}\right)$. A high $G_{4 j}$ means the country is highly exposed to supply disruptions and a low $G_{4 j}$ means the country is less vulnerable supply disruptions.

Equation 11: 3.15 Gross Inland Consumption $\left(G_{5}\right)$

$$
G_{5 j}=\frac{T G C_{j}}{P_{j}}
$$

The adjustment below transforms the indicator to an interval of $(0,1)$ with the value of 0 assigned to the highest value of the selected security of supply indicator, and less risky to supply disruptions, while the value of 1 is assigned to the country with the lowest value of the selected indicator, hence most vulnerable.

Equation 12: Relative indicator $\varphi_{5 j}$

$$
\varphi_{5 j}=\frac{G_{5}-\min \left(G_{5}\right)}{\max G_{5}-\min \left(G_{5}\right)}
$$

To ensure the sanity of the calculation, a value of 0 is assigned to countries which do not import natural gas. 


\section{Empirical results and discussion}

\section{Empirical results}

This chapter presents the gas supply security index (GSSI) of the four countries studied in this paper: Ghana, Nigeria, Cote d'Ivoire and Cameroon. The estimated GSSI for the individual countries is presented in Table 1 below, while the results of the relative indicators and indicators of gas supply security are presented in Table 2 and Table 3, respectively. A high GSSI score indicates a country's rate of vulnerabilities to natural gas supply disruptions.

Table 1. Gas Supply Security Index (GSSI)

\begin{tabular}{|l|c|c|c|c|}
\hline Indicators & Ghana & Nigeria & Cote d'Ivoire & Cameroon \\
\hline GSSI & 0.68 & 0.67 & 0.62 & 0.18 \\
\hline
\end{tabular}

Source: Based on the author's calculation.

Table 2. Relative Indicators of Gas Supply Security

\begin{tabular}{|l|c|c|c|c|}
\hline \multicolumn{1}{|c|}{ Indicators } & Ghana & Nigeria & Cote d'Ivoire & Cameroon \\
\hline$\varphi_{1}$ & 0.45 & 0.52 & 1.00 & 0.00 \\
\hline$\varphi_{2}$ & 1.00 & 0.00 & 0.00 & 0.00 \\
\hline$\varphi_{3}$ & 0.00 & 1.00 & 0.41 & 0.41 \\
\hline$\varphi_{4}$ & 1.00 & 0.00 & 0.00 & 0.00 \\
\hline$\varphi_{5}$ & 0.37 & 1.00 & 0.87 & 0.00 \\
\hline
\end{tabular}

Source: Based on the author's calculation.

Table 3. Indicators of Gas Supply Security

\begin{tabular}{|l|c|c|c|c|}
\hline \multicolumn{1}{|c|}{ Indicators } & Ghana & Nigeria & Cote d'Ivoire & Cameroon \\
\hline $\mathrm{G}_{1(\mathrm{mtoe} / \$ \mathrm{bn})}$ & 0.03 & 0.03 & 0.06 & 0.01 \\
\hline $\mathrm{G}_{2(\%)}$ & 6.83 & 0.00 & 0.00 & 0.00 \\
\hline $\mathrm{G}_{3(\%)}$ & 0.04 & 2.39 & 1.00 & 1.00 \\
\hline $\mathrm{G}_{4}$ & 0.08 & 0.00 & 0.00 & 0.00 \\
\hline $\mathrm{G}_{5 \text { (per capita) }}$ & 42.86 & 91.41 & 81.10 & 14.36 \\
\hline
\end{tabular}

Source: Based on the author's calculation. 


\section{Discussion}

\subsection{Cameroon}

Based on the results of the GSSI calculation, Cameroon appeared to be the least vulnerable to disruption in natural gas supply among the countries sampled for this study. Cameroon has a gas intensity of $0.01 \mathrm{mtoe} / \$ \mathrm{bn}$, which implies that the country's economy is not heavily dependent on natural gas. Figure 4 below demonstrates that the share of natural gas in Cameroon's energy mix sources is approximately $4 \%$. Also, Cameroon does not import natural gas, and its ratio of domestic gas production to consumption is 100 per cent, therefore, scoring a Shannon-Wiener-Neumann index of zero (0) which means that Cameroon is not exposed to the risk of supply disruptions from natural gas exporting countries which could be politically unstable. Although Cameroon has a political stability rating of $15 \%$, any domestic disruptions to natural gas production may not have a huge impact on the country since the economy has only $4 \%$ dependence on natural gas to produce goods and services.

Figure 4. Cameroon Primary Energy Sources

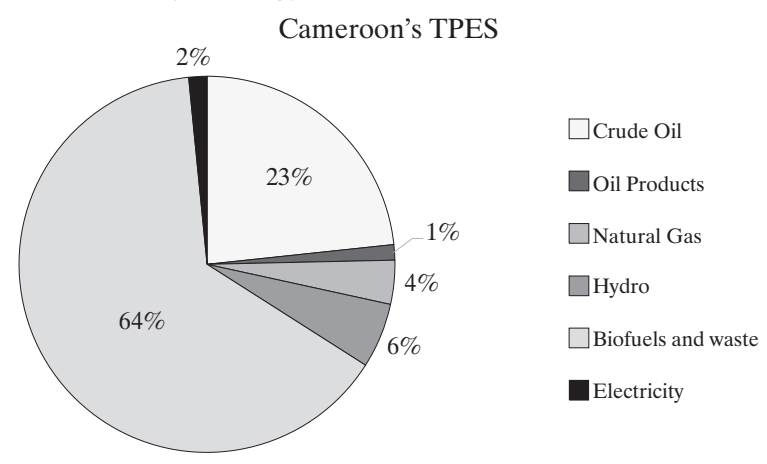

Source: IEA, 2015.

\subsection{Cote d'Ivoire}

Cote d'Ivoire is ranked the second less vulnerable country among the sampled countries for this study. The country has the highest gas intensity among the four countries studied. This implies that Cote d'Ivoire's economy relies heavily on natural gas, and this is evidenced by its high gas intensity and high gas per capita ratios. Also, as illustrated in Figure 5 below, approximately $44 \%$ of Cote d'Ivoire primary energy source is accounted for by natural gas. Despite the heavy reliance on natural gas, Cote d'Ivoire does not import gas but rather relies on its domestic production. Thus, making it less vulnerable to 
Figure 5. Cote d'Ivoire Primary Energy Sources

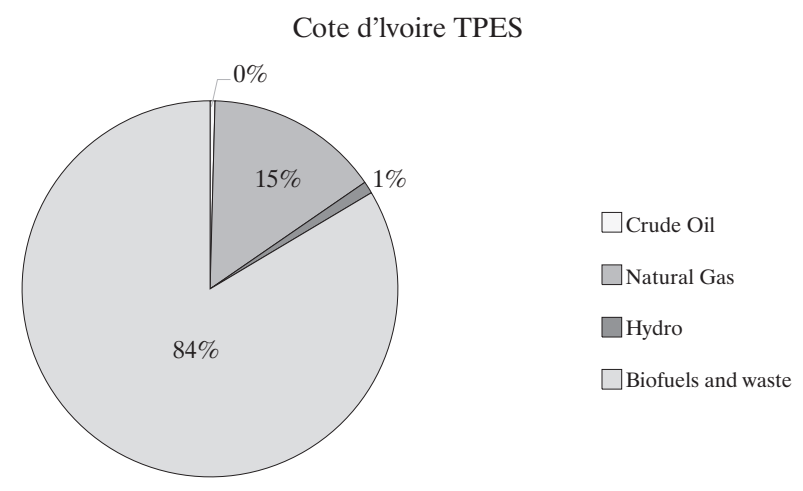

Source: EIA, 2015.

supply shocks. However, Cote d'Ivoire has a political stability rating of $20 \%$. Therefore, any disruption to domestic gas supply would make the country highly vulnerable to gas supply security.

\subsection{Nigeria}

Nigeria has the largest proven natural gas reserve in Africa and yet it is more vulnerable to natural gas supply disruption based on the figures obtained from the GSSI calculation. In 2015, Nigeria produced 39.65mtoe of natural gas, flared $11.65 \%$ of the total production, exported 23.09 mtoe and consumed $16.65 \mathrm{mtoe}$ (IEA, 2015). The natural gas intensity of Nigeria is $0.03 \mathrm{mtoe} / \$$ bn and gross inland consumption of 91.41 per capita, which is an indication that despite being the largest producer of natural gas in Africa, Nigeria's economy does not revolve around natural gas. As shown in Figure 6 below, natural

Figure 6. Nigeria's Primary Energy Sources

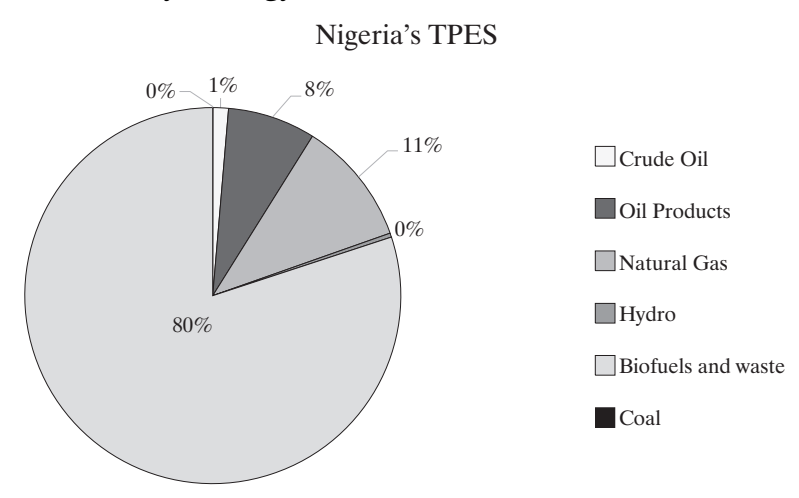

Source: IEA, 2015. 
Figure 7. Natural Gas Consumption

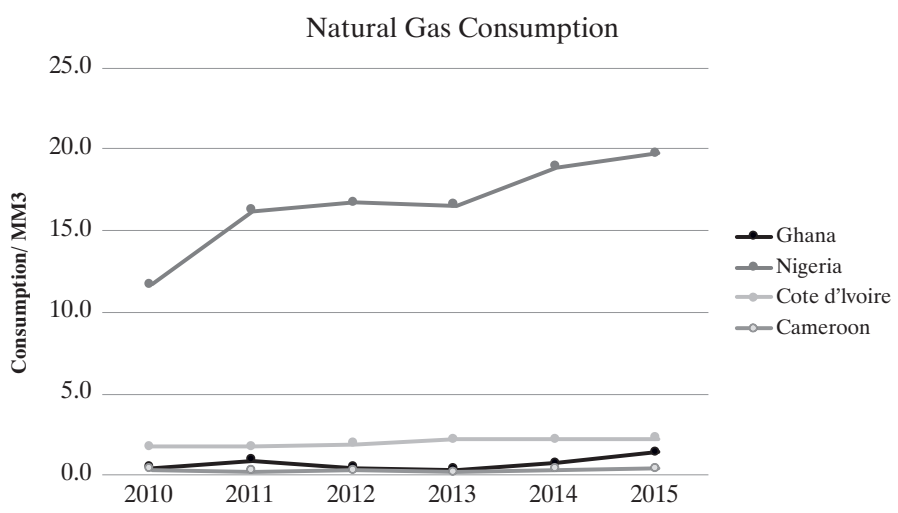

Source: IEA, 2015.

gas usage in Nigeria accounts for only $11 \%$ of Nigeria's total primary energy sources (TPES). The major energy source in Nigeria's energy mix is biofuel, which accounts for $84 \%$ of the TPES.

\subsection{Ghana}

Ghana is most vulnerable to natural gas supply disruptions among the sampled countries with a GSSI of 0.68 . Ghana is weak on all the supply security indicators, especially $\mathrm{G}_{2}, \mathrm{G}_{3}$, and $\mathrm{G}_{4}$, where the country performed poorly. The country is a net importer of natural gas from Nigeria, which has a very low political stability ranking of $6 \%$. This means that Ghana faces a high risk of supply disruption from Nigeria. For instance, from 2014 to 2016, Ghana experienced power crisis because of disruptions in gas supply from Nigeria,

Figure 8. Primary Energy Sources in Ghana

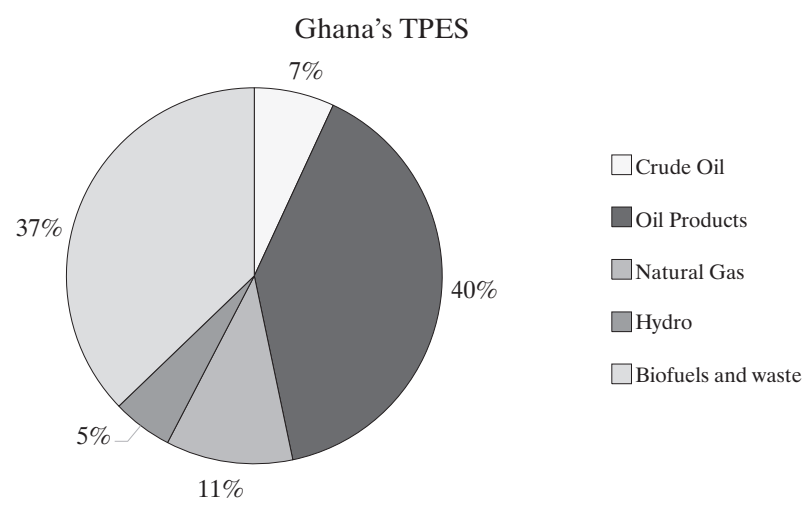

Source: IEA, 2015. 
which according to the World Bank estimates costs the country about $1 \%$ lost growth in GDP per year.

Natural gas constitutes $11 \%$ of the total primary energy mix in Ghana (this is illustrated in Figure 8 below) with an intensity of $0.03 \mathrm{mtoe} / \$ \mathrm{bn}$. This implies that Ghana's economy does not rely heavily on natural gas to produce goods and services.

\section{Conclusion and recommendation}

Based on the information gathered from the literature review and the GSSI calculation, one of the major findings identified by this study is the fact that most of the countries studied do not have a diversified source of natural gas supply. Instead, these countries mainly rely on domestic production for their security of supply, amidst very low political stability ratings, as indicated in Table 3 above. In addition, the study has not learned of any gas storage facility in any of the countries studied to safeguard the continuous supply of natural gas. Therefore, any disruptions in domestic gas production are likely to adversely impact on the natural gas supply security.

The study has, therefore, identified the followings as factors that may influence the vulnerability of natural gas supply security in the countries studied: Gas Intensity; Net Gas Import Dependency; the ratio of Domestic Gas Production to Imports; Gross Inland Consumption; Geopolitical Risk, diversity of supply, dependency on the largest supplier.

The above factors were used as indicators to estimate the GSSI of the countries studied and found out that Ghana, Nigeria and Cote d'Ivoire scored $68 \%, 67 \%$ and $62 \%$ of vulnerability to supply security respectively. Cameroon, on the other hand, emerged as the least vulnerable with a rate of $18 \%$. This implied that the above three countries are highly vulnerable to disruptions in natural gas supply security. Therefore, governments' interventions are recommended to develop policies to address the individual countries' weaknesses concerning the indicators used in this study.

The followings are, therefore, recommended by this paper to address the above challenge:

First, natural gas supply source must be diversified to include gas supplied from very high political stability countries. Second, investment in natural gas storage facilities to secure supply in case of any disruptions to domestic production. 


\section{Literature}

Ang, B.W., Choong, W.L. and Ng, T.S. (2014). Energy security: Definitions, dimensions and indexes. Renewable and Sustainable Energy Reviews, 42, 1077-1093, https://doi. org/10.1016/j.rser.2014.10.064.

Biresselioglu, M.E., Yelkenci, T. and Oz, I.O. (2014). Investigating the natural gas supply security: A new perspective. Energy Journal, 80, 168-176, https://dx.doi.org/10.1016/j. energy.2014.11.060.

BP. (2017). BP Statistical Review of World Energy June 2017. British Petroleum.

Cabalu, H. (2010). Indicators of security of natural gas supply in Asia. Energy Policy, 38(1). 218-225, https://dx.doi.org/10.1016/j.enpol.2009.09.008.

Centoni, M. (2016). Energy security: a review of studies of the economic value of energy security. Universita' Degli Studi Di Padova.

Cherp, A., et al. (2012). Energy and Security. International Institute for Applied Systems Analysis .

Cherp, O., and Jewell, J. (2010). Measuring energy security: From universal indicators to contextualized framework. In: R.V. Sidortsov (ed.), The Routledge Handbook of Energy Security, London: Routledge, https://dx.doi.org/10.4324/9780203834602.ch17.

Chester, L. (2009). Conceptualising energy security and making explicit its polysemic nature. Energy Policy, 38(2), 887-895, https://dx.doi.org/10.1016/j.enpol.2009.10.039.

Chung, W.-S. et al. (2017). A conceptual framework for energy security evaluation of power sources in South Korea. Energy, 136, 1066-1074, https://dx.doi.org/10.1016/j. energy.2017.03.108.

Franki, V. and Višković, A. (2015). Energy security, policy and technology in South East Europe: Presenting and applying an energy security index to Croatia. Energy, 90, 494-507, https://dx.doi.org/10.1016/j.energy.2015.07.087.

Frondel, M. and Schmidt, M.C. (2008). Measuring Energy Security - A Conceptual Note. Ruhr Economic Papers, 52, https://ddx.oi.org/10.2139/ssrn.1161141.

Geng, J.-B., and Ji, Q. (2013). Multi-perspective analysis of China's energy supply security. Energy, 64(2014), 541-550, https://dx.doi.org/10.1016/j.energy.2013.11.036.

Global Energy Institute. (2017). Energy Security Risk Index See more at: https://www. globalenergyinstitute.org/energy-security-risk-index. Retrieved from Global Energy Institute: https://www.globalenergyinstitute.org/energy-security-risk-index (30.09.2019).

Gupta, E. (2008). Oil vulnerability index of oil-importing countries. Energy Policy, 36(3), 1195-1211, https://dx.doi.org/10.1016/j.enpol.2007.11.011.

IEA. (2011). Measuring Short-term Energy Security. Retrieved from International Energy Agency: https:/www.iea.org/publications/freepublications/publication/Moses.pdf (30.09.2019).

IEA. (2015). Statistics. Retrieved from International Energy Agency: https://www.iea.org/ statistics/statisticssearch/report/?year $=2015 \&$ country $=$ NIGERIA\&product $=$ Balances (30.09.2019).

Kanchana, K., and Unesaki, H. (2015). Assessing Energy Security Using Indicator-Based Analysis: The Case of ASEAN Member Countries. Social Sciences, 4(4), 1269-1315.

Kisel, E. et al. (2016). Concept for Energy Security Matrix. Energy Policy, 95, 1-9, https:// dx.doi.org/10.1016/j.enpol.2016.04.034. 
Li, Y. et al. (2016). Evaluating energy security of resource-poor economies: A modified principle component analysis approach. Energy Economics, 58, 211-221, https://dx.doi. org/10.1016/j.eneco.2016.07.001.

Mohsin, M., Zhou, P., Iqbal, N. and Shah, S.A.A. (2018). Assessing oil supply security of South Asia. Energy, 155, 438-447, https://dx.doi.org/10.1016/j.energy.2018.04.116.

Pavlović, D., Banovac, E. and Vištica, N. (2017). Defining a composite index for measuring natural gas supply security - The Croatian gas market case. Energy Policy, 114, 30-38, https://dx.doi.org/10.1016/j.enpol.2017.11.029.

Reymond, M. (2012). Measuring vulnerability to shocks in the gas market in South America. Energy Policy, 48, 754-761, https://dx.doi.org/10.1016/j.enpol.2012.06.011.

Somorin, T.O. and Kolios, A.J. (2017). Prospects of deployment of Jatropha biodiesel-fired plants in Nigeria'spower sector. Energy Journal, 135, 726-735, ttps://dx.doi.org/10.1016/j. energy.2017.06.152.

Sovacool, B.K. and Mukherjee, I. (2011). Conceptualizing and measuring energy security: A synthesized approach. Energy, 36(8), 5343-5355, https://dx.doi.org/10.1016/j. energy.2011.06.043.

Winzer, C. (2012). Conceptualizing energy security. Energy Policy, 46, 36-48, https://dx.doi. org/10.1016/j.enpol.2012.02.067.

Wirba, A.V. et al. (2014). Renewable energy potentials in Cameroon: Prospects and challenges. Renewable Energy, 76, 560-565, https://dx.doi.org/10.1016/j.renene.2014.11.083.

Zhang, D., Xunpeng, S. and Sheng, Y. (2015). Comprehensive measurement of energy market integration in East Asia: An application of dynamic principal component analysis. Energy Economics, 52, 299-305, https://dx.doi.org/10.1016/j.eneco.2015.11.006. 


\section{Appendix}

Global Primary Energy Consumption

\begin{tabular}{|c|c|c|c|c|c|c|}
\hline \multicolumn{7}{|c|}{ Primary Energy Consumption } \\
\hline Oil & Natural Gas & Coal & Nuclear Energy & Hydro electric & Renew-ables & Total \\
\hline 4418.2 & 3204.1 & 3732.0 & 592.1 & 910.3 & 419.6 & 13276.3 \\
\hline
\end{tabular}

\section{Global Natural Gas Consumption}

\begin{tabular}{|c|c|c|c|c|c|c|}
\hline \multicolumn{7}{|c|}{ Natural Gas Consumption } \\
\hline Year & $\begin{array}{c}\text { Total North } \\
\text { America }\end{array}$ & $\begin{array}{c}\text { Total S. \& } \\
\text { Cent. America }\end{array}$ & $\begin{array}{c}\text { Total Europe } \\
\text { \& Eurasia }\end{array}$ & $\begin{array}{c}\text { Total Middle } \\
\text { East }\end{array}$ & $\begin{array}{c}\text { Total } \\
\text { Africa }\end{array}$ & $\begin{array}{c}\text { Total Asia } \\
\text { Pacific }\end{array}$ \\
\hline 2000 & 720.5 & 86.6 & 886.1 & 171.4 & 51.8 & 265.3 \\
\hline 2001 & 691.3 & 91.1 & 906.9 & 188.4 & 59.1 & 281.8 \\
\hline 2002 & 715.4 & 92.3 & 913.4 & 201.5 & 62.4 & 295.1 \\
\hline 2003 & 709.4 & 96.2 & 940.4 & 211.3 & 66.6 & 320.3 \\
\hline 2004 & 712.1 & 106.6 & 961.3 & 234.3 & 73.2 & 340.7 \\
\hline 2005 & 711.5 & 111.1 & 982.9 & 251.3 & 76.5 & 365.9 \\
\hline 2006 & 707.6 & 121.9 & 1003.3 & 266.7 & 80.6 & 392.9 \\
\hline 2007 & 739.9 & 128.4 & 1011.4 & 289.6 & 87.0 & 421.8 \\
\hline 2008 & 747.0 & 129.1 & 1018.9 & 312.5 & 90.6 & 449.8 \\
\hline 2009 & 740.5 & 123.0 & 937.2 & 323.2 & 89.6 & 462.0 \\
\hline 2010 & 770.0 & 135.2 & 1006.5 & 356.9 & 95.8 & 509.8 \\
\hline 2011 & 788.6 & 135.4 & 983.5 & 363.0 & 101.9 & 553.8 \\
\hline 2012 & 819.5 & 143.6 & 966.6 & 373.5 & 108.6 & 598.6 \\
\hline 2013 & 843.9 & 148.7 & 949.0 & 396.3 & 110.9 & 605.6 \\
\hline 2014 & 862.0 & 152.0 & 905.0 & 414.7 & 114.3 & 624.9 \\
\hline 2015 & 881.2 & 158.3 & 909.2 & 444.3 & 122.2 & 631.6 \\
\hline 2016 & 886.8 & 154.7 & 926.9 & 461.1 & 124.3 & 650.3 \\
\hline
\end{tabular}


Global Natural Gas Production

\begin{tabular}{|c|c|c|c|c|c|c|}
\hline & \multicolumn{6}{|c|}{ Natural Gas Production } \\
\hline Year & $\begin{array}{c}\text { Total North } \\
\text { America }\end{array}$ & $\begin{array}{c}\text { Total S. \& } \\
\text { Cent. America }\end{array}$ & $\begin{array}{c}\text { Total Europe } \\
\text { \& Eurasia }\end{array}$ & $\begin{array}{c}\text { Total Middle } \\
\text { East }\end{array}$ & $\begin{array}{c}\text { Total } \\
\text { Africa }\end{array}$ & $\begin{array}{c}\text { Total Asia } \\
\text { Pacific }\end{array}$ \\
\hline 2000 & 681.0 & 91.6 & 841.4 & 189.6 & 119.4 & 249.2 \\
\hline 2001 & 697.0 & 95.8 & 848.4 & 211.7 & 123.1 & 256.8 \\
\hline 2002 & 679.2 & 99.2 & 867.9 & 227.4 & 128.4 & 273.8 \\
\hline 2003 & 682.0 & 108.4 & 898.2 & 239.4 & 138.8 & 292.2 \\
\hline 2004 & 670.4 & 121.1 & 921.3 & 266.5 & 145.5 & 311.8 \\
\hline 2005 & 668.3 & 126.5 & 924.1 & 289.0 & 159.3 & 337.0 \\
\hline 2006 & 685.4 & 138.7 & 938.0 & 309.2 & 173.3 & 352.2 \\
\hline 2007 & 695.7 & 145.9 & 934.0 & 334.7 & 183.1 & 367.0 \\
\hline 2008 & 713.2 & 146.7 & 960.0 & 360.6 & 190.8 & 385.5 \\
\hline 2009 & 718.9 & 142.0 & 853.1 & 380.0 & 179.7 & 405.3 \\
\hline 2010 & 731.4 & 149.6 & 919.0 & 445.8 & 191.9 & 441.5 \\
\hline 2011 & 772.2 & 150.2 & 929.2 & 475.9 & 188.4 & 451.2 \\
\hline 2012 & 798.7 & 156.1 & 923.0 & 499.2 & 192.9 & 454.9 \\
\hline 2013 & 806.1 & 158.1 & 929.4 & 528.5 & 185.7 & 465.3 \\
\hline 2014 & 857.1 & 159.2 & 902.9 & 542.4 & 186.3 & 484.9 \\
\hline 2015 & 890.0 & 160.2 & 895.9 & 554.3 & 189.0 & 505.7 \\
\hline 2016 & 870.1 & 159.3 & 900.1 & 574.0 & 187.5 & 521.9 \\
\hline
\end{tabular}

2015 Data on GSSI Indictors

\begin{tabular}{|c|c|c|c|c|c|c|c|c|}
\hline \multicolumn{9}{|c|}{2015 Country Data } \\
\hline Country & 泀 & 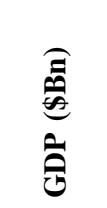 & 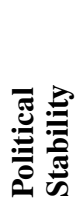 & 佥 & 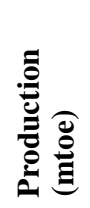 & 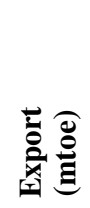 & 总总 & 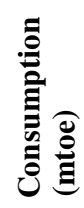 \\
\hline Nigeria & 181.18 & 481.07 & 0.06 & 139.37 & 39.65 & 23.09 & 0.00 & 16.56 \\
\hline Ghana & 27.58 & 37.54 & 0.44 & 9.70 & 0.05 & 0.00 & 0.66 & 1.18 \\
\hline Cote d'Ivoire & 23.11 & 33.15 & 0.20 & 12.98 & 1.87 & 0.00 & 0.00 & 1.87 \\
\hline Cameroon & 22.83 & 30.92 & 0.15 & 7.79 & 0.33 & 0.00 & 0.00 & 0.33 \\
\hline
\end{tabular}


Data on Total Primary Energy Sources (TPES)

\begin{tabular}{|l|c|c|c|c|}
\hline \multicolumn{1}{|c|}{ TPES } & Ghana & Nigeria & Cote d'Ivoire & Cameroon \\
\hline Energy Sources & $\%$ & & & \\
\hline Coal & 0.00 & 29.00 & 0.00 & 0.00 \\
\hline Crude Oil & 673.00 & 1855 & 48 & 1818 \\
\hline Oil Products & 3868.00 & 10529.00 & -1377 & 103 \\
\hline Natural Gas & 1064.00 & 14901.00 & 1686 & 295 \\
\hline Nuclear & 0.00 & 0.00 & 0 & 0 \\
\hline Hydro & 503.00 & 492.00 & 116.00 & 436.00 \\
\hline Geothermal, Solar, etc & 0.00 & 0.00 & 0.00 & 0.00 \\
\hline Biofuels and waste & 3617.00 & 111566.00 & $9,395.00$ & $5,020.00$ \\
\hline Electricity & -28 & 0 & -78.00 & 122.00 \\
\hline
\end{tabular}

